\begin{tabular}{|c|c|}
\hline Title & $\begin{array}{l}\text { Kerogen morphology and geochemistry at the Permian-Triassic transition in the Meishan section, South China: } \\
\text { Implication for pal eoenvironmental variation }\end{array}$ \\
\hline Author(s) & Sawada, Ken; Kaiho, Kunio; Okano, Kazuki \\
\hline Citation & $\begin{array}{l}\text { Journal of A sian Earth Sciences, 54.55, 78-90 } \\
\text { https://doi.org/10.1016/.jseaes.2012.04.004 }\end{array}$ \\
\hline Issue Date & 2012-08-02 \\
\hline Doc URL & http:/hdl. handle.net/2115/50280 \\
\hline Type & article (author version) \\
\hline File Information & JAES54-55_78-90.pdf \\
\hline
\end{tabular}

Instructions for use 


\title{
Kerogen morphology and geochemistry at the Permian-Triassic transition in the Meishan section, South China: implication for paleoenvironmental variation
}

\author{
Ken Sawada $^{1}$, Kunio Kaiho ${ }^{2}$, Kazuki Okano ${ }^{1}$ \\ 1: Department of Natural History Sciences, Faculty of Science, Hokkaido University, N10W8, Kita-ku, \\ Sapporo 060-0810, Japan \\ Phone: +81-11-706-2733, Fax: +81-11-746-0394 \\ E-mail: sawadak@mail.sci.hokudai.ac.jp \\ 2: Institute of Geology and Paleontology, Tohoku University, Sendai 980-8578, Japan
}

\begin{abstract}
:
Detailed fluorescent microscopic observations and organic geochemical analyses for insoluble sedimentary organic matter (kerogens) are conducted on the end-Permian to earliest Triassic sediments in the Meishan section A of South China. The main objectives of the present study are to reconstruct variations of marine and terrestrial environments, and to evaluate bulk characteristics of terrestrial input in the palaeo-Tethys ocean for the Permian - Triassic boundary (PTB). Most of kerogens in the Meishan section are mainly composed of marine algae-derived amorphous organic matter, while terrestrial plant-derived amorphous organic matter is remarkably dominant in the mass extinction horizon reported previously. The relative abundances of marine organic matter may vary depending on marine production rather than terrestrial input in the palaeo-Tethys associated with changing terrestrial vegetation. We also identified aromatic furans as major compounds in kerogen pyrolysate of all layers. It is possible that sources of aromatic furans with alkyl group, fungi and lichen, proliferated as disaster biota in terrestrial ecosystem through the PTB. Higher abundances of herbaceous organic matter are observed in the layers above the mass extinction horizon. However, the conifer biomarker retene can be identified in kerogen pyrolysates of all layers. These results imply that the productions of herbaceous plants increased as dominant pioneer biota in early stage of recovery for terrestrial ecosystem after its collapse, but also that woody plant potentially continued to be produced in land area throughout the end-Permian and earliest-Triassic.
\end{abstract}

Keywords: Permian - Triassic boundary, mass extinction, kerogen, fluorescent microscopic observation, terrestrial devastation, aromatic furan, retene

\section{Introduction}

The Permian - Triassic boundary (PTB; $251.4 \pm 0.3 \mathrm{Ma}$ ago) interval is marked by the most drastic mass extinction in the Phanerozoic records, with about $90 \%$ of marine species, $70 \%$ of terrestrial vertebrate genera, and most land plants dying out (Raup, 1979; Erwin, 1994; Retallack et al., 1996). In particular, many palynological studies suggested that terrestrial ecosystem was severely devastated for the PTB interval. Terrestrial palynological data indicated decline of conifer pollen abundances (Looy et al., 1999; 2001) and predominance of fungal remain (Eshet et al., 1995; Visscher et al., 1996; Steiner et al., 2003) for the PTB crisis, as well as increase of bryophyte and herbaceous lycopsid spore abundances during the early Triassic (Looy et al., 1999; 2001). These data point to preferential dieback of woody vegetation, collapse of forest, and surviving bryophyte- and herbaceous lycopsid-dominant vegetation. In addition, several abnormal morphotypes of spore and pollen were identified in the PTB sediments from Europe, Africa and Asia, which shows globally increasing mutagenesis of terrestrial plants under 
extreme environmental conditions (Visscher et al., 2004; Foster and Afonin, 2005). Furthermore, sedimentological investigations showed no sedimentation of peat nor formation of coal (Retallack et al., 1996; Michaelsen, 2002) and sudden change in fluvial system possibly attributed to loss of rooted plant (Michaelsen, 2002; Arche and Lopez-Gomez, 2005). Recently, geochemical studies suggested that terrigenous materials might be excessively supplied to the ocean during the PTB, resulting in disturbance of shallow-marine ecosystem via increasing turbidity, brackishness and eutrophication (Korte et al., 2003; Sephton et al., 2005). Remarkable abundances of soil-derived organic molecules such as dibenzofuran in end-Permian strata from northern Italy showed occurrence of massive soil erosion and transport of soil materials to the ocean as results of destruction of terrestrial vegetation (Sephton et al., 2005). However, high abundances of dibenzofuran and biphenyl, which is likely to be originated from woody plants, could be observed in the interval below the mass extinction event in the Permian - Triassic Schuchert Dal Formation (East Greenland) and Hovea-3 section (Western Australia) (Fenton et al., 2007). In addition, Fenton et al. (2007) pointed out that the erosive event was thought to be rather short-lived, and did not support 'the extinction - soil erosion scenario' of Sephton et al. (2005). Recently, Nabbefeld et al. (2010a) reported that abundances of terrigenous biomarkers such as dibenzofuran, biphenyl and coronene, which is attributed to forest-fire combustion, rapidly increased at the horizon that was onset of marine transgression, and decreased to minima above the horizon of marine ecosystem collapse in the end-Permian strata of the Lusitaniadalen, Spitsbergen, Norway. The increases of terrigenous biomarker abundances could be explained as a result of accumulation in coastal plain sediments due to sea level rise by transgression. Also, they demonstrated that the minima of terrigenous biomarker abundances might reflect terrestrial ecosystem collapse, which was nearly synchronous to collapse of marine ecosystem, although increase of distance from paleoshoreline was also considered.

In the Meishan section of South China, the Global Stratotype Section and Point (GSSP) for the PTB, the most extensive and detailed results associated with the processes of mass extinction, collapses of marine and terrestrial ecosystems, rapid climatic changes, and environmental disturbance have been reported. There has been many organic geochemical investigations for green sulfur bacteria-derived isorenieratane (Grice et al., 2005), cyanobacteria-derived 2-methyl hopane (Xie et al., 2005), terrigenous biomarkers such as dibenzofuran and alkylphenol (Wang and Visscher, 2007), hopane (Wang, 2007), and polycyclic aromatic hydrocarbon (PAH; Nabbefeld et al., 2010b) analyses in the Meishan section. Increases of abundances of dibenzofuran and alkylphenol (Wang and Visscher, 2007) and hopane (Wang, 2007) above the horizon of marine mass extinction event suggested an excessive supply of terrigenous materials to the eastern part of the palaeo-Tethys due to massive soil erosion as a consequence of devastation of terrestrial vegetation during end-Permian, consistent with the hypothesis of Sephton et al. (2005). Cyanobacterial biomarker records of the Meishan section suggested a two episode mass extinction in marine ecosystem (Xie et al., 2005), which coincided with marine faunal records reported by Yin et al. (1996). Also, Cao et al. (2009) reported marine paleoecological variations recorded by biomarkers such as hopanes, steranes, and isorenieratane in the Meishan section.

Kaiho et al. $(2006 ; 2009)$ reestablished the timings and stratigraphic position of horizons where mass extinction and environmental disturbance are present in the Meishan PTB, and the mass extinction horizon is determined to be located between 31 and $19 \mathrm{~mm}$ below the top of Bed 24e of the Changhsing Formation in the Meishan section. In the present study, we focus on the sedimentary insoluble organic matter (kerogen) from the Meishan section. Morphological and geochemical analyses of kerogen were performed in order to evaluate bulk characters of marine and terrestrial organisms, and to examine variations of terrestrial environment and transport of terrigenous materials for the PTB. 


\section{Lithology and Samples}

Fig. 1 shows the variations in lithology in Upper Permian (Changhsing Formation) and Lower Triassic (Yinkeng Formation) layers at the Meishan A section. The top Permian limestone bed (Bed 24e, $20 \mathrm{~cm}$ thick) in the Meishan sequences, except for the top $3 \mathrm{~cm}$ (24e-1), is dark gray limestone containing abundant calcareous microfossils. The top $3 \mathrm{~cm}(24 \mathrm{e}-2$ and 24e-3) is characterized by low carbonate content (Kaiho et al., 2006). The overlying basal part of Bed 25 is a Fe-rich grayish black thin layer (25-1; black layer). Thickness of the Bed 25-1 could be determined to be $0.1 \mathrm{~mm}$ by microscopic observation of sediment slices (Kaiho et al., 2006). In addition, the layers 24-2 $(1 \mathrm{~cm}$ thick), 24-3 $(1 \mathrm{~cm})$, and 25-1 $(0.1 \mathrm{~mm})$ contain grayish black, thin fragments, which looked like organic matter concentrates. The overlying dark yellowish orange, thin layer (25-2; orange layer; $0.3-1 \mathrm{~mm}$ thick) is mostly gypsum. The remaining part of Bed 25 (25-3; 2-4 cm thick) is a light bluish gray illite-montmorillonite clay (white clay). The subsequent dark gray shale (Bed 26; 6-8 cm thick) is mostly overlain by marl beds (Beds 27 to 29). The PTB was identified, on the basis of biostratigraphy, to be in the middle of marl Bed 27 (Yin, et al., 1996); the event-stratigraphic P-T boundary (EPTB) was placed at the base of Bed 25 (Wang, 1994).

Rock samples were sawed from the PTB beds in the outcrop sections in Meishan. In the top 3 -cm-thick limestone beds (layers 24e-2 and 24e-3), the black fragments were also collected as residue of the limestones by acid $(\mathrm{HCl})$ treatment. In the laboratory, we conducted microscopic and geochemical analyses in 1.1-mm to 4-cm-thick stratigraphic slices on well preserved samples. Numerous thin sections have been made from the same horizon to ensure that biotic information could be observed (Kaiho et al., 2006).

\section{1. Kerogen separation}

\section{Methods}

Whole rock samples were crushed to a 'rice'-sized (diameter $2-5 \mathrm{~mm}$ ) grain in an agate mortar. Crushed rock samples ( 5 to $10 \mathrm{~g}$ ) were extracted with ultrasonication, by successive treatment with methanol and dichloromethane. Thereafter, residues were treated sequentially in a water bath shaker as follows: $\mathrm{HCl} 6 \mathrm{M}\left(100 \mathrm{ml}, 60^{\circ} \mathrm{C}, 12 \mathrm{~h}\right), \mathrm{HCl} 12 \mathrm{M} / \mathrm{HF} 46 \%$ (1 / 1 v / v) $\left(100 \mathrm{ml}, 60^{\circ} \mathrm{C}, 24 \mathrm{~h}\right), \mathrm{HCl} 6 \mathrm{M}$ $\left(100 \mathrm{ml}, 60^{\circ} \mathrm{C}, 4 \mathrm{~h}\right)$. After each treatment, the supernatant was removed after centrifugation $(3000 \mathrm{rpm}$, $10 \mathrm{~min}$ ). The residue, kerogen, was sequentially washed with $\mathrm{HCl} 6 \mathrm{M} \mathrm{(x} \mathrm{2)} \mathrm{and} \mathrm{distilled} \mathrm{water} \mathrm{(x} \mathrm{5),}$ and was recovered and freeze-dried under vacuum.

\section{2. Palynofacies analysis}

Palynofacies analysis was carried out as described by Sawada (2006). Briefly, wet residual particles obtained after $\mathrm{HCl} / \mathrm{HF}$ treatment were siphoned and dropped onto non-fluorescent slides, and were then mounted in permanent slides for microscopic examination. Organic matter composition of kerogen was determined by counting 500 points at each 100- $\mu \mathrm{m}$ interval under an Olympus BX41 reflected light fluorescent microscope with an Olympus ULH100HG mercury lamp, a DM400 dichroic mirror containing a 330-385-nm excitation filter; and 420-nm-long pass barrier filter at the Department of Natural History Sciences, Hokkaido University. The light emitted was observed at $\times 200$ magnification.

Fluorescence light microscopic observation was used to differentiate among several types of amorphous particles (Sawada and Akiyama, 1994; Sawada, 2006). However, this method should be used with caution, because mature amorphous organic matter (AOM) does not fluoresce (Durand, 1980 and references therein). Therefore, we examined the identification of AOMs on the basis of both the fluorescence and the morphology under transmitted light microscope as reported by Tyson (1995), Boussafir et al. (1995), Tribovillard et al. (2001), Sawada (2006), and Ercegovac and Kostic (2006). The 
detailed morphological and fluorescent characters of each organic particle type constituting kerogen, and their possible sources are shown in Table 1.

\section{3. Pyrolysis-gas chromatography (GC) analysis of kerogen}

Pyrolysis-GC analysis was performed on-line using a Shimadzu Pyr-4a pyrolysis unit at the Faculty of Science, Hokkaido University. Kerogen samples were weighted (ca. $100 \mu \mathrm{g}$ ) into $3 \mathrm{~mm}$ x $3 \mathrm{~mm}$ platinum (Pt) bucket. The bucket was placed in the sample holder, which is affixed to the top of the Pyr-4a, for 5 min keeping the bucket at room temperature under a He gas stream. The sample bucket was then dropped into the heated zone maintained isothermal at $450{ }^{\circ} \mathrm{C}$. Identification of pyrolytic compounds was carried out by gas chromatography - mass spectrometry (GC-MS) with a Shimadzu GC17A attached to a capillary GC $(60 \mathrm{~m} \times 0.25 \mathrm{~mm}$ i.d. DB-5 column, J \& W Scientific $)$ directly coupled to a Shimadzu QP5000 quadrupole mass spectrometer (electron voltage, $70 \mathrm{eV}$; emission current, $350 \mu \mathrm{A}$; mass range, $\mathrm{m} / z, 50-550)$ at the Faculty of Science, Hokkaido University. The injector was maintained at $315^{\circ} \mathrm{C}$ and with a splitless. The $\mathrm{GC}$ temperature was programmed as follows: $50{ }^{\circ} \mathrm{C}$ for $2 \mathrm{~min}, 50-315^{\circ} \mathrm{C}$ at $4^{\circ} \mathrm{C} / \mathrm{min}$, and $315^{\circ} \mathrm{C}$ for $15 \mathrm{~min}$.

\section{4. Elemental (CHN) analysis of kerogen}

A portion of each kerogen sample was analyzed for elemental ratios, carbon $(\mathrm{C})$, hydrogen $(\mathrm{H})$, and nitrogen (N) by a J-Science Micro Corder JM10 at the Center for Instrumental Analysis, Hokkaido University.

\section{1. Palynofacies data of kerogen}

\section{Results and Discussion}

Fig. 2 and Table 2 show photomicrographs of kerogens separated from sedimentary rocks and their palynofacies compositions from the Changhsing to Yinkeng Formations, respectively. We examined the identification of AOM on the basis of both the fluorescence and the morphology under transmitted light microscope as reported by Boussafir et al. (1995), Tribovillard et al. (2001), Sawada (2006), and Ercegovac and Kostic (2006): (1) Brown weakly-fluorescent amorphous organic matter (Br-WFA) corresponds to the light brown to dark brown AOM under transmitted light microscope (Fig. 3). This Br-WFA weekly fluoresce with a white color, and might be typical weakly fluorescent amorphous kerogen (WFA) as classified by Sawada and Akiyama (1994). Some of the Br-WFAs include pyrite framboids (Fig. 3c). (2) Orange weakly-fluorescent amorphous organic matter (Or-WFA) corresponds to the massive microscopically AOM which color was orange to reddish brown under transmitted light microscope (Fig. 3). The edge of the Or-WFA aggregate is sharp. The white to yellow fluorescence from the Or-WFA is weaker than that of the Br-WFA. (3) Fluorescent amorphous organic matter (FA) is minute grayish yellow-colored debris (Fig. 2a-2), and corresponds to the highly degraded products from spore, pollen, and cuticle of plants. In addition, FA may contain minute debris from algal cyst as very minor component. (4) Non-fluorescent amorphous organic matter (NFA) corresponds to a mixture of minute ligneous debris and non-fluorescent amorphous matter (Fig. 2). The edge of the NFA is relatively sharp. This AOM is probably formed by high degradation and fragmentation of woody tissues of higher plant and coal materials (vitrinite and/or inertinite).

In this study, we group three types of structured organic matter: (1) Phytoclast is organic debris derived from terrestrial plant tissues including wood and cuticle. Woody debris (wood) is structured opaque black to dark brown fragments with sharp angular edges under transmitted light microscope (Fig. 4a). Some of woody debris are small semi-transparent fragments. This organic matter does not fluoresce at all. Cuticle is a transparent filter-like light yellow to yellow fragment with sharp angular edges, and 
fluoresces strongly under fluorescent light microscope (Fig. 4b). (2) Palynomorph includes three types; spores and pollen (sporomorph), phytoplankton and zooplankton. Sporomorph is a transparent, relatively medium to large sized particle under transmitted light microscope. Sporomorph also fluoresce strongly under fluorescent light microscope (Fig. 2a). Phytoplankton is organic algal fossil such as acritarch, and a transparent granular particle under transmitted light microscope and fluoresces strongly under fluorescent light microscope (Figs. 4c and 4d). Zooplankton is foraminiferal lining fossil, and a semi-transparent brown to black particle and does not fluoresce (Fig. 2a). (3) Bituminite is a structured gel-like material that is orange to dark brown in color under transmitted light microscope, and moderately fluorescent with an orange to reddish orange color under fluorescent light. The bituminite is presumably originated from peculiar cuticle tissue of higher plants (Tissot et al., 1987), while Taguchi (1992) suggested that some bituminites are derived from marine algae such as red and brown algae. The bituminite is very minor component in kerogens of the Meishan sediments.

Most of kerogens in the Meishan section are mainly composed of Br-WFA, whereas NFA is remarkably dominant in the limestone layers of 24e-2 and 24e-3 (CHMIA-3.1 -2 and CHMIA-2 0 samples). The Or-WFA is relatively abundant in the shale Bed 26. Boussafir et al. (1995) and Tribovillard et al. (2001) demonstrated that orange AOM identified in the Jurassic Kimmeridge Clay kerogen was formed from labile organic matter synthesized by marine phytoplankton through sulfur incorporation, or 'vulcanization'. The Or-WFA is likely to be similar to the orange AOM in morphology under transmitted light microscope, and therefore, it is possibly vulcanization-type AOM originated from marine phytoplankton. Riboulleau et al. (2003) divided the orange AOM into two types, heterogenous and pure orange AOM, according to their inner texture. The Or-WFA in the Meishan sediments resemble to pure orange AOM. We identified commonly pyrite grains in sediments of the Meishan section, which indicates that sulfide such as $\mathrm{H}_{2} \mathrm{~S}$ was produced by sulfate reduction under anoxic condition. In general, sulfide reacts more efficiently with iron to form pyrite than with organic matter. However, if extremely high abundant sulfide is produced, sulfur possibly reacts with not only iron but also organic matter. Grice et al. (2005) reported high concentrations of isorenieratane, which was proof of photic zone euxinia, from Bed 24 to Bed 27 in the Meishan. Thus, it is postulated that excess sulfides in ocean water and sediment let to sulfur incorporation during kerogen formation, especially during the deposition of Bed 26. On the other hand, NFA is thought to correspond to a mixture dominated by minute ligneous debris as mentioned above, so that predominance of NFA in layers $24 \mathrm{e}-2$ and $24 \mathrm{e}-3$ suggests high contribution of terrigenous organic matter in kerogens of the mass extinction horizon (Table 2). However, origin of non-fluorescent AOM in marine sediment is still controversial. Non-fluorescent structureless humic matter is generally rare except terrestrial and oxic proximal marine sediments (Tyson, 1995; 2006). There is alternative view that opaque black AOM is presumably derived from marine organism, and fluorescence in AOM is lost as a result by formation of incursion such as pyrite framboids. Nevertheless, pyrite grains are not abundant in the NFA-rich layers, 24e-2 and 24e-3, and inclusion such as pyrite framboids is not observed within NFA particle in kerogens of these layers. Rather, such pyrite framboids are rich in Br-WFA as mentioned above (Fig. 3c). Hence, the NFA in the Meishan sediments is woody plant tissue origin. In contrast to majority of the AOM, well-preserved structured organic matter is very rare in the Meishan section. Nevertheless, the non-woody (herbaceous) organic matter such as sporomorphs and cuticles is relatively abundant in Bed 26. Phytoplankton and zooplankton can be identified as acritarchs and foraminiferal lining, respectively, in the Meishan section (Fig. 2), but both are minor components $(<0.1 \%)$.

The relative abundance of total marine organism-derived organic matter (Marine organic matter \%; Fig. 1 and Table 2) is calculated as follow;

Marine organic matter $(\mathrm{OM}) \%=[\mathrm{Br}-\mathrm{WFA}]+[\mathrm{Or}-\mathrm{WFA}]+[$ phytoplankton $]+[$ zooplankton $]$, where 
[] denotes the relative abundance of each organic matter.

The values of the Marine OM \% were very high in the lower and middle parts of Bed 24e, and rapidly decreased from about $80 \%$ to $20 \%$ at the top (layers $24 \mathrm{e}-2$ and $24 \mathrm{e}-3$ ). It subsequently increased to about $60 \%$ in the Bed 26, with a little decreased at the top of Bed 26. From the Bed 27, the values of Marine OM \% recover to about $70-80 \%$.

The sum of relative abundances of herbaceous organic matter and FA (FA+Herb) varied from the Changhsing to Yinkeng Formations (Fig. 1). The FA+Herb values were low in Bed 24, and then increased in Bed 26. A peak of FA+Herb can be observed in upper part of Bed 26 (CHMIA 8 10; Fig. 2a-2), corresponding to a decrease of Marine OM \% value (Fig. 1). The FA+Herb values decreased from Bed 27, and were then nearly constant, although a little increased in Bed 30. From these results, it is suggested that production of herbaceous plant increased in terrestrial area and/or herbaceous organic matter was more efficiently transported from land to ocean during the period for Bed 26.

In addition, we attempted to determine the kerogen composition in black fragments concentrating organic matter within the $24 \mathrm{e}-3$ layer (Fig. 1). It was found that the kerogens in the black fragments were predominated by Br-WFA and Or-WFA, and were quite different from that in the limestone layer of $24 \mathrm{e}-3$. As a result, the Marine OM \% in the black fragments was much higher (95\%) than that of the limestone layer in the $24 \mathrm{e}-3$ layer (Table 2). This indicates that the marine organic matter may be heterogeneously concentrated within sedimentary layers near the PTB.

\section{2. Elemental and pyrolysis-GC data of kerogen}

The $\mathrm{H} / \mathrm{C}$ and N/C ratios of kerogens are $0.08-0.37$ and $0.031-0.072$, respectively (Table 3 ). The $\mathrm{H} / \mathrm{C}$ ratios of kerogens are consistently low, and especially are the lowest in the layers $24 \mathrm{e}-2$ and $24 \mathrm{e}-3$ (CHMIA-3.1 -2 and CHMIA-2 0 samples). The $\mathrm{H} / \mathrm{C}$ ratios tend to be higher in the samples that have high Marine OM \% values. The N/C ratios are relatively high even in Permian - Triassic sediment samples, and are nearly constant in all samples. Only in kerogen in Bed 27 (CHMIA15 17), both H/C and N/C ratios are high, although these may be due to contamination of mineral. Cao et al. (2009) reported that maturity levels estimated by $\mathrm{C}_{31}$ homohopane isomer ratios were uniformly the earliest stage of 'oil window' (earliest catagenesis) in the Meishan sediments near the PTB. The low values of $\mathrm{H} / \mathrm{C}$ are concordant with the earliest catagenetic level, but the N/C appears high values. Such high values of N/C might be attributed to nitrogen moiety in refractory organic matter and/or inorganic nitrogen sources from minerals, although its reason is unclear. The higher $\mathrm{H} / \mathrm{C}$ ratios in the samples that have high Marine OM \% values are concordant with the general trend that the $\mathrm{H} / \mathrm{C}$ of marine kerogen is higher than that of terrigenous kerogen (Ishiwatari, 1985). On the other hand, the lowest values of H/C in the samples that have high NFA (layers $24 \mathrm{e}-2$ and 24e-3) supports that the NFA is terrigenous woody organic matter origin. Sawada (2006) confirmed that the vitrinite (wood) and NFA- rich fraction of kerogen had a relatively low $\mathrm{H} / \mathrm{C}$ ratio, which agrees with the $\mathrm{H} / \mathrm{C}$ results of this study.

Fig. 5 shows pyrolysis-GC-MS chromatograms of kerogens in the layers of $24 \mathrm{e}-2$ and $24 \mathrm{e}-3$, as well as Bed 26 (CHMIA-3.1 -2, CHMIA-2 0 and CHMIA 8 10 samples). $n-\mathrm{C}_{8}$ to $n$ - $\mathrm{C}_{25}$ alkanes and alk-1-enes are identified in all kerogen pyrolysates from the Changhsing to Yinkeng Formations. Polycyclic aromatic hydrocarbons (PAHs) such as naphthalene and phenanthrene, alkyl phenols, and aromatic furans and thiophenes can be also identified. Distributions of compounds in pyrolysates are nearly constant in all kerogens from Bed 24e to Bed 30 in this study. However, the relative abundances of aromatic furans are slightly higher in $24 \mathrm{e}-2$ and $24 \mathrm{e}-3$ layers. The $\mathrm{C}_{2}$ alkyl phenols in pyrolysate can only be detected from samples of Bed 24e (layer 24e-1 and 24e-2; Fig. 5), Bed 27 and Bed 29. Wang and Visscher (2007) reported that PAHs, aromatic thiophenes and furans, as well as phenolic compounds were identified by the pyrolysis-GC-MS for kerogens from the Changhsing to Yinkeng 
Formations of the Meishan section. In more detailed search for minor compounds in pyrolysates, we can identify benzofuran, dibenzofuran, benzonaphthofurans, and their alkyl derivatives (Figs. 5 and 6). The benzofuran has not been identified in previous studies of the PTB sediments, and the benzonaphthofurans described only by Sephton et al. (1999). These aromatic furans can be derived from oxygen-containing aromatic moieties within structure of kerogen. Furthermore, we can identify retene, which is a diagenetic product from diterpenoid of terrestrial plant, especially conifer (Simoneit et al., 1986; Otto and Wilde, 2001; Nakamura et al., 2010), in all kerogen pyrolysates from Bed 24e to Bed 30 (Figs. 5 and 7). Retene is usually identified as free compound from mature sediments, although it is not completely excluded that the retene is possibly produced by pyrolysis of algal compounds (Wen et al., 2000). Therefore, it may be compound that was not covalently bound in kerogen rather than moiety within structure of kerogen. It has been shown that terpenoid hydrocarbons can be occluded into geomacromolecule such as kerogen during diagenesis (Curiale et al., 1983; Ekweozor, 1984; Sawada, 2004). Thus, it can be implicated that retene in pyrolysates was presumably trapped and/or occluded to the kerogen during diagenesis in the Meishan section. Interestingly, the relative abundance of peak of retene in pyrolysate chromatogram is slightly higher in a CHMIA 8 10 sample of Bed 26 (Fig. 5), although pyrolysis-GC analysis can not provide precise quantitative data.

\section{3. Further evidences of aromatic furans in kerogen in the Meishan sediments}

Fig. 6 shows mass fragmentograms and mass spectra of aromatic furans in pyrolysates. The highest levels of dibenzofuran and its alkyl $\left(\mathrm{C}_{1}-\mathrm{C}_{3}\right)$ derivatives are observed in pyrolysates from kerogen in Bed 24e of the Meishan section as reported by Wang and Visscher (2007). Furthermore, a benzofuran and its alkyl derivatives as well as benzonaphthofurans can be also identified as pyrolysates in this study. In addition to the Meishan section, the dibenzofuran and $\mathrm{C}_{1}$ - to $\mathrm{C}_{4}$-alkyldibenzofurans have been detected as pyrolysate and solvent-extractable compound in Val Badia (Sephton et al., 1999; 2005) and the Vigo Meano section (Watson et al., 2005) in the northern Italy. The benzonaphthofurans have been also identified as solvent-extractable compound in Val Badia (Sephton et al., 1999). The solvent-extractable dibenzofuran and $\mathrm{C}_{1}$ - to $\mathrm{C}_{4}$-alkyldibenzofurans could be detected as major compounds in Bed 23 to Bed 30 of the Meishan section (highest levels occur from Bed 23 to Bed 26; Wang and Visscher, 2007). Source(s) for these aromatic furans have been suggested to be polysaccharides such as cellulose (Sephton et al., 1999; 2005) and lignin (Fenton et al., 2007) in terrestrial plant, phenols (Born et al., 1989), phytoalexins in fungal-inoculated sapwood tissue of terrestrial higher plants (Kokubun et al., 1995), and lipids that had skeletons of benzofuran and dibenzofuran in lichen (Radke, 2000; Takenaka et al., 2004). In addition, Watanabe (2000) demonstrated that only benzofuran and dibenzofuran could be yielded from cellulose, cellubiose, lignin, and biphenol in simulated maturation experiments (by heating at $200^{\circ} \mathrm{C}$ for $12-24$ hours within sealed glass tube adding clay mineral and water), whereas their alkyl derivatives and benzonaphthofurans could not be yielded. Therefore, it is likely that the aromatic furans with alkyl group detected in previous and the present studies might be originated from lipids that had aromatic furan skeletons rather than polysaccharides and lignin. Thus, we suggest that the aromatic furans with alkyl group in kerogen pyrolysates originated from fungi and lichen biolipids . Non-alkylated benzofuran and dibenzofuran were presumably mixed origins, lichen / fungi-derived lipids and cellulose / lignin. Watson et al. (2005) interpreted the increase of aromatic furans in the Vigo Meano end-Permian marls of northern Italy as the result of progressive expansion of fungi and lower plants during a period of ecological stress. Consistent with this interpretation, significant levels of the alkylated dibenzofurans at Bed 24 to Bed 30 imply that fungi and lichen were abundantly produced and widely covered terrestrial barren areas, resulting from preferential dieback of woody vegetation and collapse of forest as suggested by Looy et al. (1999). 
Subsequently, the terrigenous materials derived from fungi and lichen might be efficiently supplied to the palaeo-Tethys attributed to devastation of terrestrial vegetation.

\section{4. Palaeoenvironmental variations in the PTB recorded by kerogen analyses}

The relative abundances of terrestrial plant-derived organic matter such as NFA rapidly increased, that is, those of marine organic matter rapidly decreased, at the marine biota mass extinction horizon (the $24 \mathrm{e}-2$ to $24 \mathrm{e}-3$ interval) reported by Kaiho et al. (2006). In the present study, the Marine OM \% distinctly decreased in the layers $24 \mathrm{e}-2$ and $24 \mathrm{e}-3$ (Fig. 1). Because total organic carbon (TOC) content of sediments hardly changed in these layers, but rather, rapid increase of TOC is observed above the horizons (Kaiho et al., 2009; Fig. 1), we suggest that the elevated relative abundances of terrestrial organic matter in kerogen are resulting from decline of marine production rather than from dilution by abundant terrigenous organic matter such as NFA. Wang and Visscher (2007) suggested that enrichment of dibenzofuran and its alkyl derivatives across the Meishan PTB showed excessive supply of terrigenous materials to the eastern part of palaeo-Tethys, resulting from massive soil erosion due to destruction of terrestrial vegetation. Indeed, the ratios of free dibenzofuran homologues to total aromatic hydrocarbons ((OF+MOF) / tAr) increased and dibenzofuran homologues were more abundant in kerogen pyrolysates in Bed 23 to Bed 26. However, the dibenzofuran homologues could be detected as free compounds in not only the extinction horizon but also in the other layers, and the (OF+MOF) / tAr values varied with small ranges of about $0.05-0.3$. Also, the enriched dibenzofuran homologues in kerogen pyrolysates were observed in only clayish sediments such as black shale and black micrite. Maturation experiments for humic substances with or without clay have shown that clay minerals are efficient catalyst for aromatization (Faure et al., 2006). These things indicated that the relative abundances of dibenzofuran and its derivatives were controlled by lithological characters of sediments. In addition, it can be reasonable demonstration that erosive event was rather short-lived (Fenton et al., 2007), and marine production and ecology were not continuously affected by extensive soil erosion as suggested by Sephton et al. (2005). However, kerogen morphological and pyrolysis data in the present study also support several palynological and sedimentological results indicating collapse and devastation of terrestrial ecosystems in the Pangea during the PTB, such as dieback of woody vegetation, massive loss of rooted plant, and cease of peat formation (Retallack et al., 1996; Looy et al., 1999; Michaelsen, 2002; Arche and Lopez-Gomez, 2005). The significant abundances of benzofuran, dibenzofuran, benzonaphthofuran, and their alkyl derivatives in the present study imply that fungi and lichen were widely produced on the seedbed formed by massive deposition of senescent woods in the destroyed forests, and a large amount of organic materials biosynthesized by these organisms were continuously transported to ocean. The speculation of aromatic furans in this study is supported by palynological results for the proliferation of fungal remains (Eshet et al., 1995; Visscher et al., 1996; Steiner et al., 2003). The fungi and lichen-derived materials may be transported by usual riverine and/or aeolian systems rather than by eventual soil erosion from land to ocean, although this is only speculative.

The relative abundances of NFA gradually decreased, resulting in increase of marine organic matter, in Bed 25 to Bed 27. Moreover, terrestrial ecosystem was presumably recovered above Bed 24e. Interestingly, there is a spike of the FA+Herb values in upper layer of Bed 26. This result suggests that herbaceous plants were remarkably dominant as pioneer plants in terrestrial ecosystem during early stage of recovery. Vajda and McLoughlin (2007) reviewed the recovery pattern of terrestrial vegetation during the PTB, and summarized that only fungal/algal palynomorph proliferated as disaster biota just after the mass extinction and damage of terrestrial ecosystem, then the opportunistic herbaceous lycopsids and fern increased, and subsequently pleuromeiid lycopsids, peltasperms and voltzialean conifers were abundant, and at last a diverse gymnosperm-rich floras were gradually returned. They 
estimated the timing of appearance of pioneer herbaceous plants to be less than $2-5 \times 10^{4}$ years after the mass extinction. The Bed 26 to Bed 27 were thought to be deposited in $10^{4}$ to $10^{5}$ years after the mass extinction on the basis of age dating by Bowring et al. (1999). Thus, it seems that the timing of the high abundance of herbaceous organic matter in upper layer of Bed 26 was slightly later than that increasing pioneer herbaceous plant such as lycopsid and fern as suggested by Vajda and McLoughlin (2007). At that time, transport efficiency of terrigenous materials abundantly containing herbaceous plant possibly increased with a short duration. Then, the relative abundance of the herbaceous organic matter decreased above Bed 26, which implied recovery of woody flora and decline of terrigenous material transport to ocean. Nevertheless, the detection of retene, which is derived from woody plant such as conifer, can be identified as pyrolysate from all kerogen in Bed 24e to Bed 30, especially more enrichment of Bed 26. Fenton et al. (2007) also reported that the retene was identified as free compound from the Schuchert Dal PTB sediments, and the retene concentration increased just above the extinction horizon. The elevated concentrations of retene correspond with lycopsid-dominant interval in the Schuchert Dal section, suggesting that herbaceous plants such as lycopsids are a likely source of retene. Possibility of algae- and bryophyte-derived retenes has also been suggested by previous studies (Wen et al., 2000; Romero-Sarmiento et al., 2010; 2011). However, there is no direct evidence that retene is also derived from bryophyte and herbaceous lycopsid. In addition, the occurrence of retene in kerogen pyrolysates is coeval with that of the NFA in the palynofacies, so that its origin from not algae but terrestrial plant in the present study cannot be doubtful. Thus, it should be thought that the retene is derived from conifer plants. The detection of retene in kerogen pyrolysates above the mass extinction horizon implies that woody plants representative of conifer were not completely lost during and after the period of the terrestrial ecosystem crisis. Hence, it is suggested that the herbaceous plant like lycopsid was dominant in flora, but also woody plant continued to be produced in terrestrial vegetation throughout the end-Permian to earliest Triassic.

Also, the decrease of marine organic matter suggests an abrupt decrease in marine productivity associated with a decrease in phosphorus that occurs in 24e-2 layer (Kaiho et al., 2006). The layers 24e-2 and 24e-3 corresponds to the extinction horizon (Kaiho et al., 2006), and the increase of the Marine OM \% above the extinction horizon and the high values in Bed 26 (Fig. 1) suggests that an increase in algae may have occurred in an abnormal marine environment like acidic oceans (Kaiho et al., 2001; Liang, 2002) and ecosystems after the mass extinction. A recovery of Marine OM \% occurred in Bed 27. This suggests that marine productivity recovered in $10^{4}$ to $10^{5}$ years after the mass extinction estimated by Bowring et al. (1999). The recovery of marine productivity is prior to the recovery of benthos (brachiopoda) inhabiting the shallow sea, which occurred $10^{6}$ years after the mass extinction (Chen et al., 2002).

\section{Conclusion}

Marine and terrestrial organisms and ecosystems, and variations of terrestrial palaeoenvironment are reconstructed from the records of palynofacies compositions and pyrolysates in kerogens from the end-Permian to earliest-Triassic sediments in the Meishan section A of South China.

Most of organic matter is mainly composed of marine algae-derived AOMs, while terrestrial plant-derived AOMs are overwhelmingly dominant in the mass extinction horizon reported by Kaiho et al. (2006). The variations of relative abundances of marine (/terrestrial) organic matter may be controlled by marine production rather than terrestrial input in ocean.

In this study, further evidences for many types of aromatic furans can be added to insights of a previous report (Wang and Visscher, 2007) by kerogen pyrolysis in the Meishan section. The significant levels of aromatic furans in kerogen pyrolysates are observed in all sedimentary layers. We suggest that 
the aromatic furans with alkyl group are likely to be originated from fungi and lichen rather than polysaccharide and lignin in soil, and thus, the significant levels of these compounds suggested proliferation of fungi and lichen as disaster biota during the destruction of terrestrial vegetation. However, we do not agree with the hypothesis that excessive supply of terrigenous materials due to massive soil erosion as suggested by Sephton et al. (2005).

The relative abundances of herbaceous organic matter also varied in the Meishan sediments, and higher abundances of herbaceous organic matter are observed in the layers just above the mass extinction horizon. However, conifer plant biomarker such as retene can be identified in kerogen pyrolysates of all layers. These results imply production of the herbaceous plant increased as dominant pioneer biota in early stage of recovery for terrestrial ecosystem after its crisis, but also woody plant potentially continued to be produced in land area throughout the end-Permian and earliest-Triassic.

As shown here, integrated microscopic and geochemical investigations for kerogens using ancient sediment such as the end-Permian are effective in reconstructing marine and terrestrial ecological variations. In future, it will be necessary to investigate kerogen from ancient sediments deposited in the other environmental disturbance events such as the Cretaceous - Paleogene boundary for reconstructing the paleoenvironmental and paleoecological variations for marine and terrestrial ecosystems.

Acknowledgments: We are grateful to Prof. N. Suzuki for use and valuable advice of pyrolysis GC/MS, and Dr. A. Riboulleau as well as an anonymous reviewer for constructive comments. This work was partly supported by a grant-in-aid for scientific research from the Japan Society for the Promotion of Science. This study was supported in part by Grants-In-Aid No. 11440152 (to KK), and Nos.18684028 and 20606001 (to KS) for Scientific Research from the Ministry of Education, Culture, Sports, Science and Technology of Japan.

\section{References}

Arche, A., López-Gómez, J., 2005. Sudden changes in fluvial style across the Permian-Triassic boundary in the eastern Iberian Ranges, Spain: analysis of possible causes. Palaeogeography, Palaeoclimatology, Palaeoecology 229, 104-126.

Born, J.G.P., Louw, R., Mulder, P., 1989. Formation of dibenzodioxins and dibenzofurans in homogenous gas-phase reactions of phenols. Chemosphere 19, 401-406.

Boussafir, M., Gelin, F., Lallier-Verges, E., Derenne, S., Bertrand, P., Largeau, C., 1995. Electron microscopy and pyrolysis of kerogens from the Kimmeridge Clay Formation, UK: Source organisms, preservation processes, and origin of microcycles. Geochimica et Cosmochimica Acta 59, 3731-3747.

Bowring, S.A., Erwin, D.H., Isozaki, Y., 1999. The tempo of mass extinction and recovery: The end-Permian example. Proceedings of the National Academy of Sciences of the United States of America 96, 8827-8828.

Bowring, S.A., Erwin, D.H., Jin, Y.G., Martin, M.W., David, E.K., Wang, W., 1998. U/Pb zircon geochronology and tempo of the end-Permian mass extinction. Science 280, 1039-1045.

Cao, C., Love, G.D., Hays, L.E., Wang, W., Shen, S., Summons, R.E., 2009. Biogeochemical evidence for euxinic oceans and ecological disturbance presaging the end-Permian mass extinction event. Earth and Planetary Science Letters 281, 188-201.

Chen, Z., Shi, G.R., Kaiho, K., 2002. A new genus of Rhynchonellid brachiopod from the Lower Triassic of South China and implications for timing the recovery of brachiopoda after the end-Permian mass extinction: Palaeontology 45, 149-164.

Curiale, J.A., Harrison, W.E., Smith, G., 1983. Sterane distribution of solid bitumen pyrolysates. Changes with biodegradation of crude oil in the Ouachita Mountains, Oklahoma. Geochimica et Cosmochimica Acta 47, 517-523.

Durand, B., 1980. Kerogen - Insoluble Organic Matter from Sedimentary Rocks. Editions Technip, Paris, 519p.

Ekweozor, C. M., 1984. Tricyclic terpenoid derivatives from chemical degradation reactions of asphaltenes. Organic Geochemistry 6, 51-61.

Ercegovac, M., Kostic, A., 2006. Organic facies and palynofacies: nomenclature, classification and applicability for 
petroleum source rock evaluation. International Journal of Coal Geology 68, 70-78.

Erwin, D.H., 1994. The Permo-Triassic extinction: Nature 367, 231-236.

Eshet, Y., Rampino, M.R., Visscher, H., 1995. Fungal event and palynological record of ecological crisis and recovery across the Permian-Triassic boundary. Geology 23, 967-970.

Faure, P., Schlepp, L., Mansuy-Huault, L., Elie, M., Jardé, E., Pelletier, M., 2006. Aromatization of organic matter induced by the presence of clays during flash pyrolysis-gas chromatography - mass spectrometry (PyGC-MS). A major analytical artifact. Journal of Analytical and Applied Pyrolysis 75, 1-10.

Fenton, S., Grice, K., Twitchett, R.J., Böttcher, M.E., Looy, C.V., Nabbefeld, B., 2007. Changes in biomarker abundances and sulfur isotopes of pyrite across the Permian-Triassic (P/Tr) Schuchert Dal section (East Greenland). Earth and Planetary Science Letters 262, 230-239.

Foster, C.B., Afonin, S.A., 2005. Abnormal pollen grains: an outcome of deteriorating atmospheric conditions around the Permian-Triassic boundary. Journal of Geological Society 162, 653-659.

Grice, K., Cao, C., Love, G.D., Bottcher, M.E., Twitchett, R.J, Grosjean, E., Summons, R.E., Turgeon, S.C., Dunning, W., Jin, Y., 2005. Photic zone euxinia during the Permian - Triassic superanoxic event. Science 307, 706-709.

Ishiwatari, R., 1985. Geochemistry of humic substances. In: Aiken, G. R., McKnight, D. M., Wershaw, R. L., MacCarthy, P. (Eds.), Humic substances in soil, sediment, and water: geochemistry, isolation, and characterization. John Wiley \& Sons, New York, pp. 147-180.

Kaiho, K., Chen, Z.-Q., Kawahata, H., Kajiwara, Y., Sato, H., 2006. Close-up of the end-Permian mass extinction horizon recorded in the Meishan section, South China: Sedimentary, elemental, and biotic characterization and a negative shift of sulfate sulfur isotope ratio. Palaeogeography, Palaeoclimatology, Palaeoecology 239, 396-405.

Kaiho, K., Chen, Z-Q. and Sawada, K., 2009. Possible causes for a negative shift in the stable carbon isotope ratio before, during and after the end-Permian mass extinction in Meishan, South China. Australian Journal of Earth Sciences 56, 799-808.

Kokubun T., Harborne J. B., Eagles J., Waterman P. G., 1995. Dibenzofuran phytoalexins from the sapwood of Cotoneaster acutifolius and five related species. Phytochemistry 38, 57-60.

Korte, C., Kozur, H.W., Bruckschen, P., Veizer, J., 2003. Strontium isotope evolution of Late Permian and Triassic seawater. Geochimica et Cosmochimica Acta 67, 47-62.

Liang, H., 2002. End-Permian catastrophic event of marine acidification by hydrated sulfuric acid: mineralogical evidence from Meishan section of South China. Chinese Scientific Bulletin 47, 1393-1397.

Looy, C.V., Brugman, W.A., Dilcher, D.L., Visscher, H., 1999. The delayed resurgence of equatorial forests after the Permian-Triassic ecological crisis. Proceedings of the National Academy of Sciences of the United States of America 96, 13857-13862.

Looy, C.V., Twitchett, R.J., Dilcher, D.L., Van Konijnenburg-Van Cittert, J.H.A., Visscher, H., 2001. Life in the end-Permian dead zone. Proceedings of the National Academy of Sciences of the United States of America 98, 7879-7883.

Michaelsen, P., 2002. Mass extinction of peat-forming plants and the effect on fluvial styles across the Permian-Triassic boundary, northern Bowen Basin, Australia. Palaeogeography, Palaeoclimatology, Palaeoecology 179, 173-188.

Nabbefeld, B., Grice, K., Twitchett, R.J., Summons, R.E., Hays, L., Böttcher, M.E., Muhammad, A., 2010a. An integrated biomarker, isotopic and palaeo- environmental study through the Late Permian event at Lusitaniadalen, Spitsbergen. Earth and Planetary Science Letters 291, 84-96.

Nabbefeld, B., Grice, K., Summons, R.E., Hays, L., 2010b. Significance of polycyclic aromatic hydrocarbons (PAHs) in Permian/Triassic boundary sections. Applied Geochemistry 25, 1374-1382.

Nakamura, H., Sawada, K., Takahashi, M., 2010. Aliphatic and aromatic terpenoid biomarkers in Cretaceous and Paleogene angiosperm fossils from Japan. Organic Geochemistry 41, 975-980.

Otto, A., Wilde, V., 2001. Sesqui-, di-, and triterpenoids as chemosystematic markers in extant conifers-A review. The Botanical Review 67, 141-238.

Radke, M., Vriend, S. P., Ramanampisoa, L. R., 2000. Alkyldibenzofurans in terrestrial rocks: Influence of organic facies and maturation. Geochimica et Cosmochimica Acta 64, 275-286.

Raup, D.M., 1979. Size of the Permo-Triassic bottleneck and it sevolutionary implications. Science 206, 217-218.

Retallack, G.J., 1995. Permian-Triassic extinction on land. Science 267, 77-80.

Retallack, G.J., Veevers, J.J., Morante, R., 1996. Global coal gap between Permian-Triassic extinction and Middle Triassic recovery of peat forming plants. Geological Society of America Bulletin 108, 195-207. 
Riboulleau, A., Baudin, F., Deconinck, J.-F., Derenne, S., Largeau, C., Tribovillard, N., 2003. Depositional conditions and organic matter preservation pathways in an epicontinental environment: the Upper Jurassic Kashpir oil shales (Volga Basin, Russia). Palaeogeography, Palaeoclimatology, Palaeoecology 197, 171-197.

Romero-Sarmiento M.-F., Riboulleau A., Vecoli M., Versteegh G.J.M., 2010. Occurrence of retene in upper Silurian Lower Devonian sediments from North Africa: Origin and implications. Organic Geochemistry 41, 302-306.

Romero-Sarmiento, M.-F., Riboulleau, A., Vecoli, M., Versteegh., G.J.M., 2011. Aliphatic and aromatic biomarkers from Gondwanan sediments of Late Ordovician to Early Devonian age: An early terrestrialization approach. Organic Geochemistry 42, 605-617.

Sawada, K., Akiyama, M., 1994. Carbon isotope composition of macerals separated from various kerogens by density separation method. Journal of the Japanese Association of Petroleum Technology 59, 244-255 (in Japanese).

Sawada, K., 2004. Degraded pentacyclic triterpenoids in the geomacromolecule: sedimentary molecules or in situ microbial products? Photo/Electrochemistry and Photobiology in Environment, Energy, and Fuel 2004 (eds, S. Kaneco, B. Viswanathan and K. Funasaka), Research Signpost, India, pp.149-164.

Sawada, K., 2006. Organic facies and geochemical aspects in Neogene neritic sediments of the Takafu syncline area of central Japan: Paleoenvironmental and sedimentological reconstructions. Island Arc 15, 517-536.

Simoneit, B. R. T., Grimalt, J. O., Wang, T. G., Cox, R. E., Hatcher, P. G., Nissenbaum, A., 1986. Cyclic terpenoids of contemporary resinous plant detritus and of fossil woods, ambers and coals. Organic Geochemistry 10, 877-889.

Sephton, M.A., Looy, C.V., Veefkind, R.J., Visscher, H., Brinkhuis, H., de Leeuw, J.W., 1999. Cyclic diaryl ethers in a Late Permian sediment. Organic Geochemistry 30, 267-273.

Sephton, M. A., Looy, C. V., Brinkhuis, H., Wingnall, P. B., de Leeuw J. W., Visscher, H., 2005. Catastrophic soil erosion during the end-Permian biotic crisis. Geology 33, 941-944.

Steiner, M.B., Eshet, Y., Rampino, M.R., Schwindt, D.M., 2003. Fungal abundance spike and the Permian-Triassic boundary in the Karoo Supergroup (South Africa). Palaeogeography, Palaeoclimatology, Palaeoecology 194, 405-414.

Taguchi, K., 1992. Recent studies on amorphous kerogens and petroleum formation. Journal of the Japanese Association of Petroleum Technology 57, 274-289 (in Japanese).

Takenaka, Y., Tanahashi, T., Nagakura, N. Itoh, A., Hamada, N., 2004. Three isocoumarins and a benzofuran from the cultured lichen mycobionts of Pyrenula sp. Phytochemistry 65, 3119-3123.

Tissot, B. P., Pelet, R., Ungerer, P. H., 1987. Thermal history of sedimentary basins, maturation indices, and kinetics of oil and gas generation: AAPG Bulletin 71, 1445-1466.

Tribovillard, N., Bialkowski, A., Tyson, R. V., Lallier-Vergès, E. Deconinck, J.-F., 2001. Organic facies variation in the late Kimmeridgian of the Boulonnais area (northernmost France). Marine and Petroleum Geology 18, 371-389.

Tyson, R.V., 1995. Sedimentary Organic Matter: Organic Facies and Palynofacies, 615p. London.

Tyson, R.V., 2006. Calibration of hydrogen indices with microscopy: a review, reanalysis and new results using the fluorescence scale. Organic Geochemistry 37, 45-63.

Vajda, V., McLoughlin, S., 2007. Extinction and recovery patterns of the vegetation across the Cretaceous-Palaeogene boundary- a tool for unraveling the causes of the end-Permian mass-extinction. Review of Palaeobotany and Palynology 144, 99-112.

Visscher, H., Looy, C. V., Collinson, M. E., Brinkhuis, H., Van Konijnenburg-Van Cittert, J. H. A., Kürschner, W. K., Sephton, M. A., 2004. Environmental mutagenesis at the time of the end Permian ecological crisis. Proceedings of the National Academy of Sciences of the United States of America 101, 12952-12956.

Visscher, H., Brinkhuis, H., Dilcher, D. L., Elsik, W. C., Eshet, Y., Looy, C.V., Rampino, M.R., Traverse, A., 1996. The terminal Paleozoic fungal event: evidence of terrestrial ecosystem destabilization and collapse. Proceedings of the National Academy of Sciences of the United States of America 93, 2155-2158.

Wang, C.J., 2007. Anomalous hopane distributions at the Permian-Triassic boundary, Meishan, China—Evidence for the end-Permian marine ecosystem collapse. Organic Geochemistry 38, 52-66.

Wang, C.J., Visscher, H., 2007. Abundance anomalies of aromatic biomarkers in the Permian-Triassic boundary section at Meishan, China- Evidence of end-Permian terrestrial ecosystem collapse. Palaeogeography, Palaeoclimatology, Palaeoecology 252, 291-303.

Wang, C.Y., 1994. A conodont-based high-resolution event-stratigraphy and biostratigraphy for the Permian-Triassic boundaries in South China. Palaeoworld 4, 234-248.

Watanabe, T., 2000. Solvent-extractable furans in sedimentary rocks: examination for their potencial sources. Master thesis of Department of Chemistry, University of Tsukuba (in Japanese). 
Watson, J. S., Sephton, M. A., Looy, C. V., Gilmour, I., 2005. Oxygen-containing aromatic compounds in a Late Permian sediment. Organic Geochemistry 36, 371-384.

Wen, Z., Ruiyong, W., Radke, M., Qingyu, W., Guoying, S., Zhili, L., 2000. Retene in pyrolysates of algal and bacterial organic matter. Organic Geochemistry 31, 757-762.

Yin, H. F., Wu, S. B., Ding, M. H., Zhang, K. X., Tong, J. N., Yang, F. Q., Lai, X. L., 1996. The Meishan section, candidate of the Global Stratotype Section and Point of Permian-Triassic Boundary, in Yin, H. F., ed., The Palaeozoic-Mesozoic Boundary candidates of Global Stratotype Section and Point of the Permian-Triassic Boundary: NSFC Project, China University of Geosciences Press, Wuhan, China, pp. 31-48.

Xie, S. C., Pancost, R. D., Yin, H. F., Wang, H. M., Evershed R. P. 2005. Two episodes of microbial change coupled with Permo/ Triassic faunal mass extinction. Nature 434, 494-497. 
Table1 Description of insoluble organic matter (kerogen) in the Meishan A samples identified under transmitted and fluorescent microscope in this study. Classification is based on Tyson (1995), Baussafir et al. (1995), Tribovillard et al. (2001), Sawada (2006), and Ercegovac and Kostic (2006).

See text for detail.

\begin{tabular}{|c|c|c|c|}
\hline Kerogen & Possible origins & Characteristics in transmitted microscope & Characteristics in fluorescent microscope \\
\hline \multicolumn{4}{|l|}{ Amorphous organic matter (AOM): } \\
\hline $\begin{array}{l}\text { Brown weakly-fluorescent amorphous } \\
\text { organic matter (Br-WFA) }\end{array}$ & Marine algae. & Brown to dark brown amorphous organic matter. & Weak white fluorescence \\
\hline $\begin{array}{l}\text { Orange weakly-fluorescent amorphous } \\
\text { organic matter (Or-WFA) }\end{array}$ & $\begin{array}{l}\text { Marine organism and } \\
\text { 'vulcanisation-type' organic } \\
\text { matter? }\end{array}$ & $\begin{array}{l}\text { Massive microscopically amorphous organic matter. } \\
\text { Orange to reddish brown color. }\end{array}$ & Weak white to yellow fluorescence \\
\hline $\begin{array}{l}\text { Fluorescent amorphous organic matter } \\
\text { (FA) }\end{array}$ & $\begin{array}{l}\text { Minute fragment of } \\
\text { terrestrial plant spore and } \\
\text { cuticle. }\end{array}$ & $\begin{array}{l}\text { Fine transparent amorphous organic matter. Minute } \\
\text { particles with sharp outlines. Transparent light yellow to } \\
\text { yellow color. }\end{array}$ & $\begin{array}{l}\text { Strongly white to yellowish white } \\
\text { fluorescence }\end{array}$ \\
\hline $\begin{array}{l}\text { Non-fluorescent amorphous organic matter } \\
\text { (NFA) }\end{array}$ & Terrestrial plant. & $\begin{array}{l}\text { Opaque dark brown to black minute particles and } \\
\text { amorphous organic matter. }\end{array}$ & Non-fluorescence \\
\hline \multicolumn{4}{|l|}{ Structured organic matter (SOM): } \\
\hline \multicolumn{4}{|l|}{ Phytoclast: } \\
\hline Wood & $\begin{array}{l}\text { Terrestrial plant woody } \\
\text { tissue. }\end{array}$ & $\begin{array}{l}\text { Opaque and semi-transparent dark brown to black particles } \\
\text { with sharp angular outlines. }\end{array}$ & Non-fluorescence \\
\hline Cuticle & $\begin{array}{l}\text { Terrestrial plant cuticle } \\
\text { tissues. }\end{array}$ & Transparent filter-like light yellow to yellow fragment. & Strongly white to yellow fluorescence \\
\hline \multicolumn{4}{|l|}{ Palynomorph: } \\
\hline Sporomorph & $\begin{array}{l}\text { Terrestrial plant spore and } \\
\text { pollen fossils. }\end{array}$ & Transparent light yellow to yellow granular particle. & Strongly white to yellow fluorescence \\
\hline Phytoplankton & Acritarch fossils. & Transparent light yellow granular particle. & Strongly white fluorescence \\
\hline Zooplankton & Foraminifera lining fossils & Transparent light orange to brown granular particle. & Non-fluorescence \\
\hline \multicolumn{4}{|l|}{ Bituminite: } \\
\hline Bituminite & $\begin{array}{l}\text { Solid bitumen and/or } \\
\text { peculier terrestrial plant } \\
\text { tissue. }\end{array}$ & Structured gel-like material. Orange to dark brown color & $\begin{array}{l}\text { Strongly to moderately orange to reddish } \\
\text { orange fluorescence }\end{array}$ \\
\hline
\end{tabular}


Table 2 Insoluble organic matter composition (\%) of the Meishan section by palynofacies analysis.

NFA: Non-fluorescent AOM, FA: Fluorescent AOM. Br- or Or-WFA: Brown or orange weakly-fluorescent AOM. tr: trace $(>0.5 \%)$.

FA+Herb.: Percentage of sum of FA and herbaceous organic matter (sporomorph and cuticle).

Marine OM\%: percentages of sum of Br-WFA, Or-WFA and phytoplankton in kerogen

CHMIA-2 0(BF): Black fragment sample in CHMIA $-2 \sim 0$

\begin{tabular}{|c|c|c|c|c|c|c|c|c|c|c|}
\hline Sample & Bed No. & NFA & FA & Br-WFA & Or-WFA & Wood & Cuticle & Sporomorph & Marine $\mathrm{OM} \%$ & $\mathrm{FA}+\mathrm{Herb}$ \\
\hline CHMIA $83-85$ & 30 & 10 & 8 & 65 & 1 & 8 & 7 & 1 & 66 & 16 \\
\hline CHMIA $58-60$ & 29 & 8 & 5 & 73 & 1 & 6 & 6 & 1 & 74 & 12 \\
\hline CHMIA $48-50$ & 29 & 10 & 2 & 77 & 1 & 5 & 5 & $\operatorname{tr}$ & 78 & 7 \\
\hline CHMIA $36.5-39$ & 29 & 5 & 3 & 81 & 3 & 3 & 4 & 1 & 84 & 8 \\
\hline CHMIA $30-33.5$ & 29 & 8 & 5 & 73 & 3 & 5 & 4 & 2 & 76 & 11 \\
\hline CHMIA 23-27 & $28 / 27$ & 7 & 3 & 81 & 3 & 1 & 5 & $\operatorname{tr}$ & 84 & 8 \\
\hline CHMIA $15-17$ & 27 & 2 & 7 & 76 & 5 & 5 & 5 & $\operatorname{tr}$ & 81 & 12 \\
\hline CHMIA 8-10 & 26 & 25 & 14 & 30 & 10 & 5 & 12 & 4 & 40 & 30 \\
\hline CHMIA 6-8 & 26 & 28 & 7 & 42 & 8 & 5 & 8 & 2 & 50 & 17 \\
\hline CHMIA 4-6 & 26 & 25 & 10 & 41 & 20 & 3 & 1 & $\operatorname{tr}$ & 61 & 11 \\
\hline CHMIA-2-0(BF) & $24 \mathrm{e}$ & 2 & 0 & 49 & 46 & 1 & 2 & $\operatorname{tr}$ & 95 & 2 \\
\hline CHMIA-2-0 & $24 \mathrm{e}$ & 62 & 5 & 16 & 8 & 4 & 5 & $\operatorname{tr}$ & 24 & 10 \\
\hline CHMIA-3.1--2 & $24 \mathrm{e}$ & 72 & 5 & 10 & 6 & 5 & 2 & $\operatorname{tr}$ & 16 & 7 \\
\hline CHMIA-7--4.6 & $24 \mathrm{e}$ & 3 & 3 & 78 & 5 & 5 & 6 & $\operatorname{tr}$ & 83 & 9 \\
\hline CHMIA-10--7 & $24 \mathrm{e}$ & 2 & 2 & 78 & 5 & 6 & 6 & 1 & 83 & 9 \\
\hline CHMIA-15--12 & $24 \mathrm{e}$ & 12 & 2 & 75 & 3 & 5 & 3 & $\operatorname{tr}$ & 78 & 5 \\
\hline
\end{tabular}


Table 3 Elemental ratios of hydrogen to carbon (H/C) and nitrogen to carbon (N/C) of kerogens in the Meishan section A.

\begin{tabular}{lccc}
\hline Sample & Bed No. & $\mathrm{H} / \mathrm{C}$ & $\mathrm{N} / \mathrm{C}$ \\
\hline CHMIA 83-85 & 30 & 0.15 & 0.030 \\
CHMIA 58-60 & 29 & - & - \\
CHMIA 48-50 & 29 & 0.22 & 0.031 \\
CHMIA 36.5-39 & 29 & 0.15 & $\mathrm{n} . \mathrm{d}$. \\
CHMIA 30-33.5 & 29 & - & - \\
CHMIA 23-27 & $28 / 27$ & - & - \\
CHMIA 15-17 & 27 & 0.37 & 0.072 \\
CHMIA 8-10 & 26 & 0.10 & 0.033 \\
CHMIA 6-8 & 26 & 0.13 & 0.038 \\
CHMIA 4-6 & 26 & 0.12 & 0.033 \\
CHMIA-2-0(BF) & $24 \mathrm{e}$ & - & - \\
CHMIA-2-0 & $24 \mathrm{e}$ & 0.09 & 0.031 \\
CHMIA-3.1--2 & $24 \mathrm{e}$ & 0.08 & 0.031 \\
CHMIA-7--4.6 & $24 \mathrm{e}$ & 0.22 & n.d. \\
CHMIA-10--7 & $24 \mathrm{e}$ & - & - \\
CHMIA-15--12 & $24 \mathrm{e}$ & 0.23 & n.d. \\
\hline n.d: not detection & & &
\end{tabular}

n.d.: not detection 


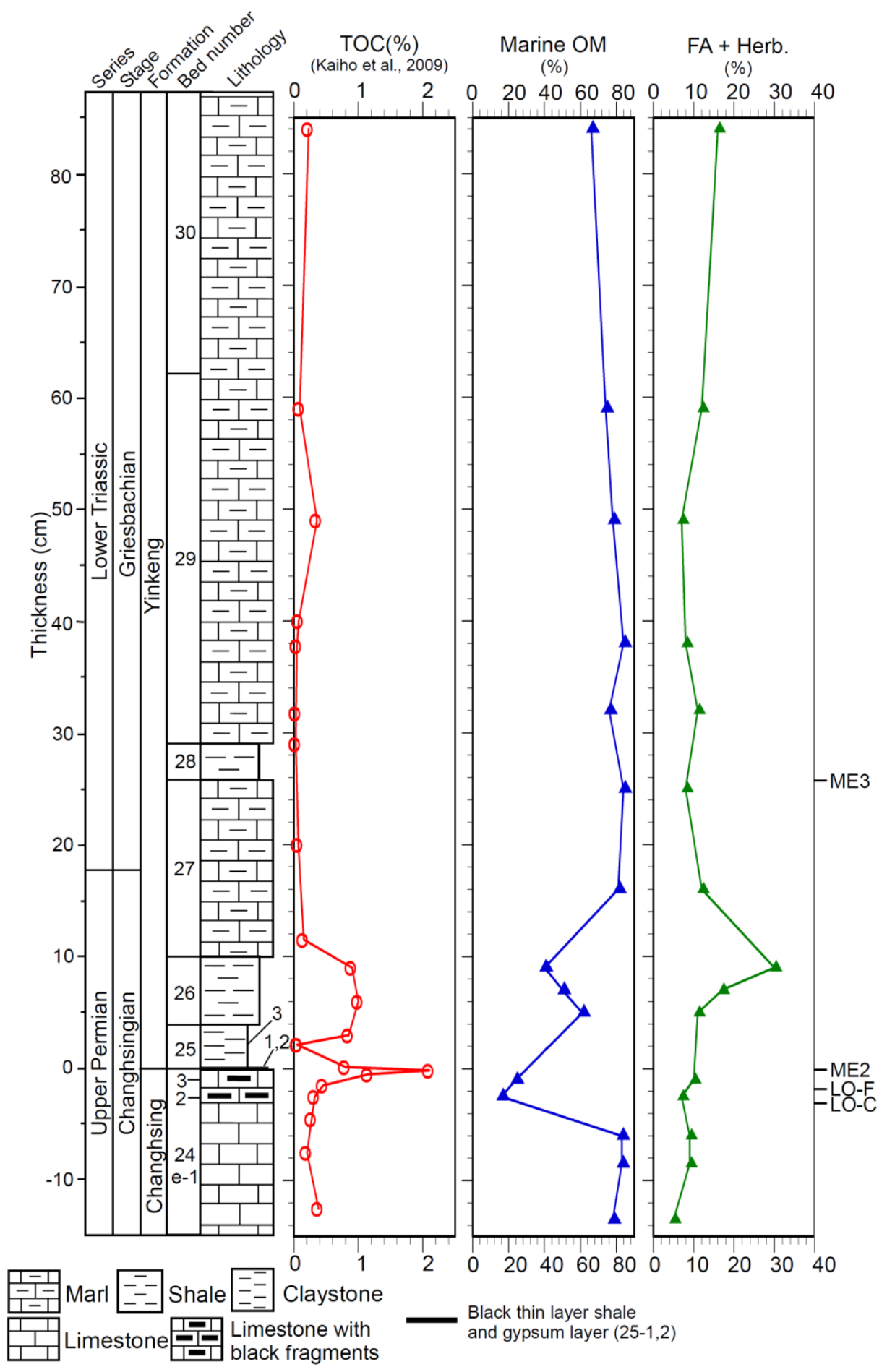

Fig. 1 Variations in lithology, total organic carbon (TOC) contents (\%; Kaiho et al., 2009), percentage of marine kerogens (Marine kerogens \%), and sum of FA and herbaceous kerogens (FA + Herb. \%) in sedimentary rocks recorded in the Upper Permian and Lower Triassic layers in the Meishan section A (South China).

Two lines '2-' and '3-' in Bed 24e indicate the bottom limits of Bed 24e-2 and Bed 24e-3, respectively. LO-C and LO-F are the last occurrences of Paleozoic coral fragments and fusulinids, respectively. Mass extinctions ME2 and ME3 show the start horizons of extinction events proposed by Yin et al. (1996). 


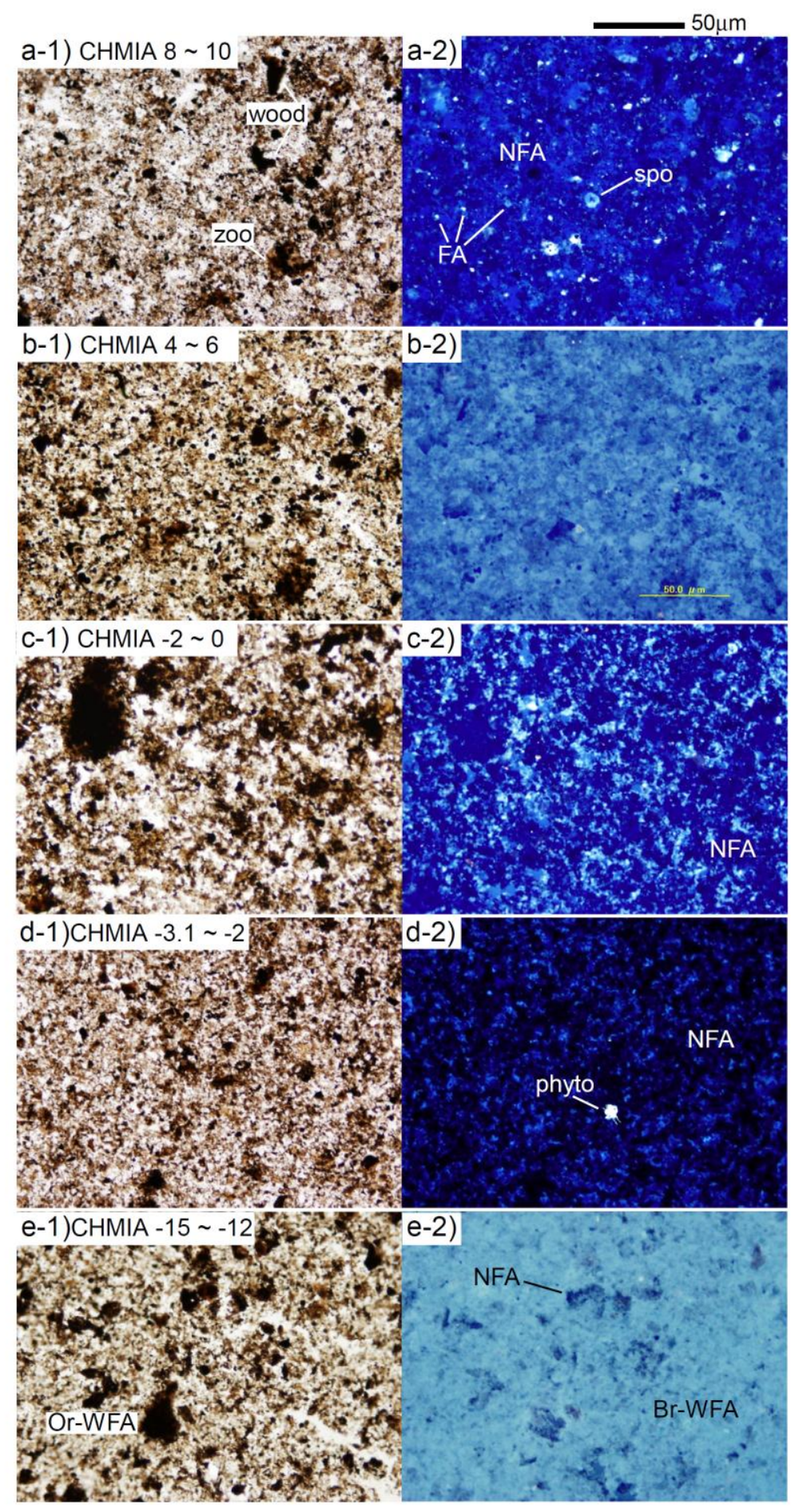

Fig. 2 Transmitted (left) and fluorescent (right) light microscopic observations of kerogens across the extinction boundary in the Meishan section A: (a-1, a-2) $8 \sim 10 \mathrm{~cm}$ (thickness in Fig. 1); (b-1, b-2) 4 6 cm; (c-1, c-2) -2 0 cm; (d-1, d-2) -3.1 -2 cm; (e-1, e-2) -15 - $12 \mathrm{~cm}$.

FA: fluorescent amorphous organic matter, NFA: non-fluorescent amorphous organic matter, Br-WFA: brown weakly-fluorescent amorphous organic matter, spo: sporomorph, phyto: phytoplankton, zoo: zooplankton (foraminifera lining?). 


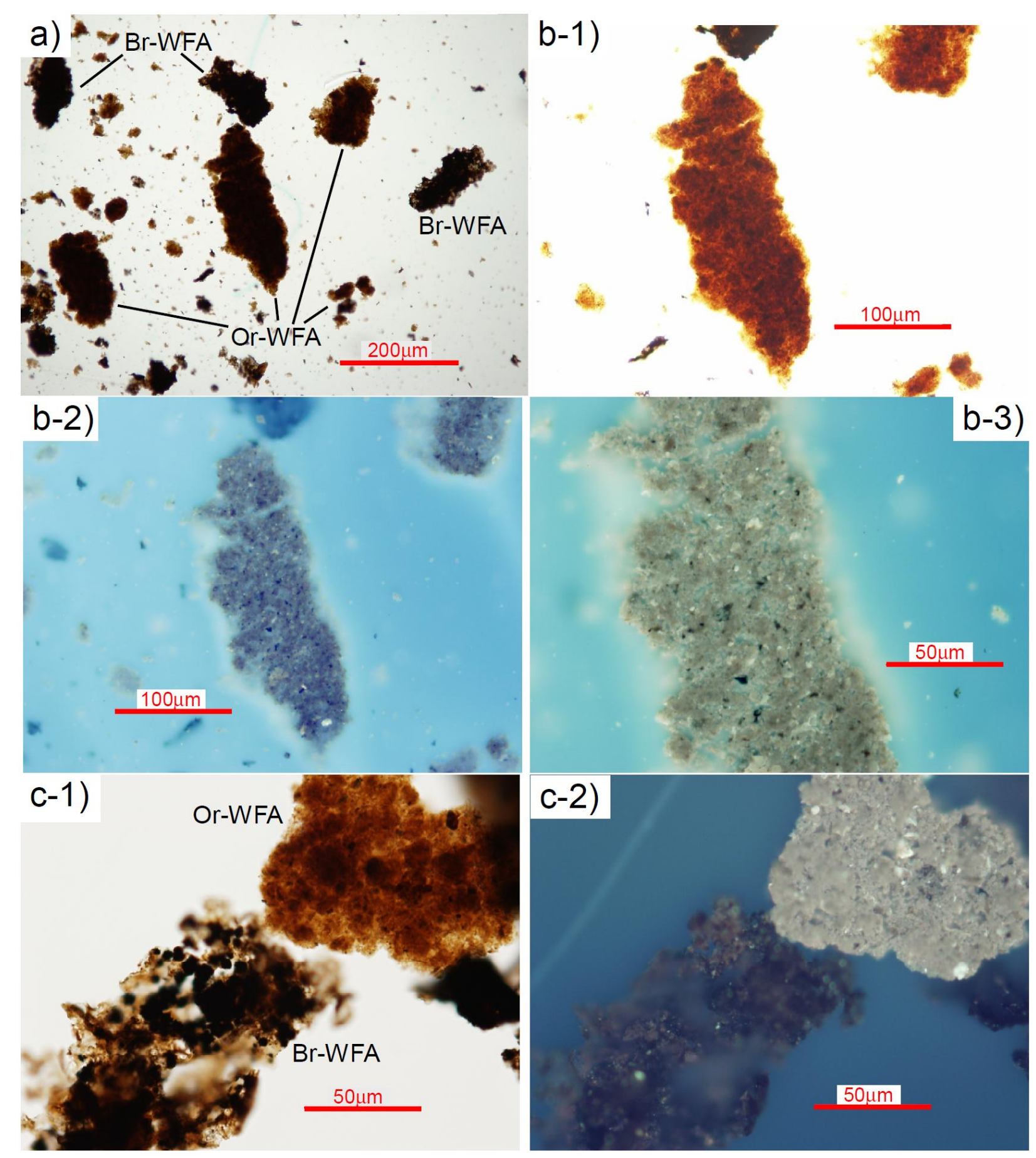

Fig. 3 Photomicrographs of amorphous organic matter in a black fragment sample in CHMIA-2 0: (a) fragments of brown weakly-fluorescent amorphous organic matter (Br-WFA) and orange weakly-fluorescent amorphous organic matter (Or-WFA) observed under transmitted light microscope; (b-1, b-2, b-3) typical Or-WFA under transmitted (b-1) and fluorescent (b-2, b-3) light microscope; (c-1, c-2) Br-WFA with framboidal pyrite and Or-WFA under transmitted (c-1) and fluorescent (c-2) light microscope. 


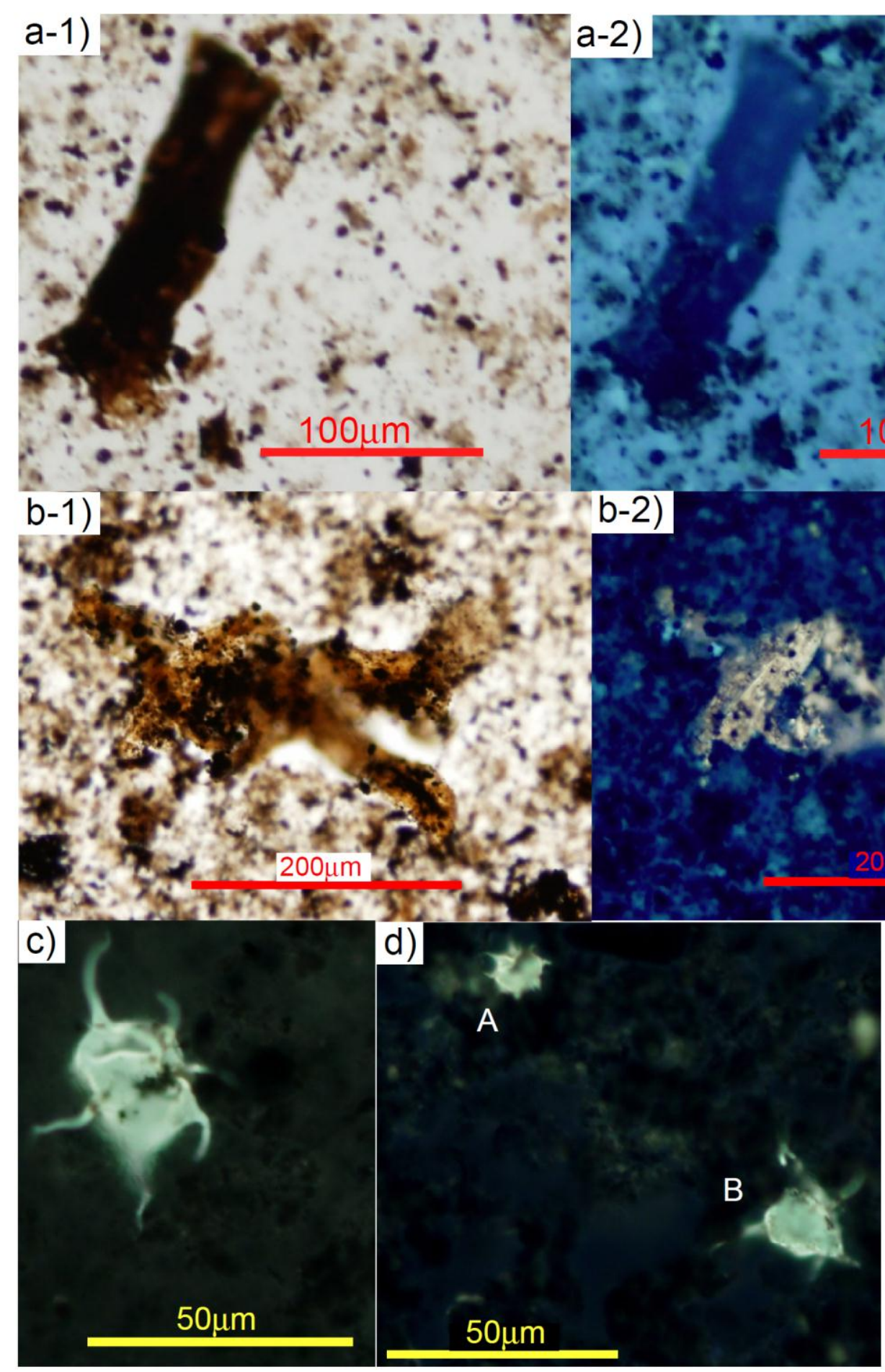

Fig. 4 Main types of palynomorphs in the Meishan section A: (a-1, a-2) A wood observed under transmitted (a-1) and fluorescent (a-2) light microscope; (b-1, b-2) a large type of cuticle under transmitted (b-1) and fluorescent (b-2) light microscope; (c) a typical phytoplankton (acritarch); (d) A: acritarch or spore, B: acritarch. 

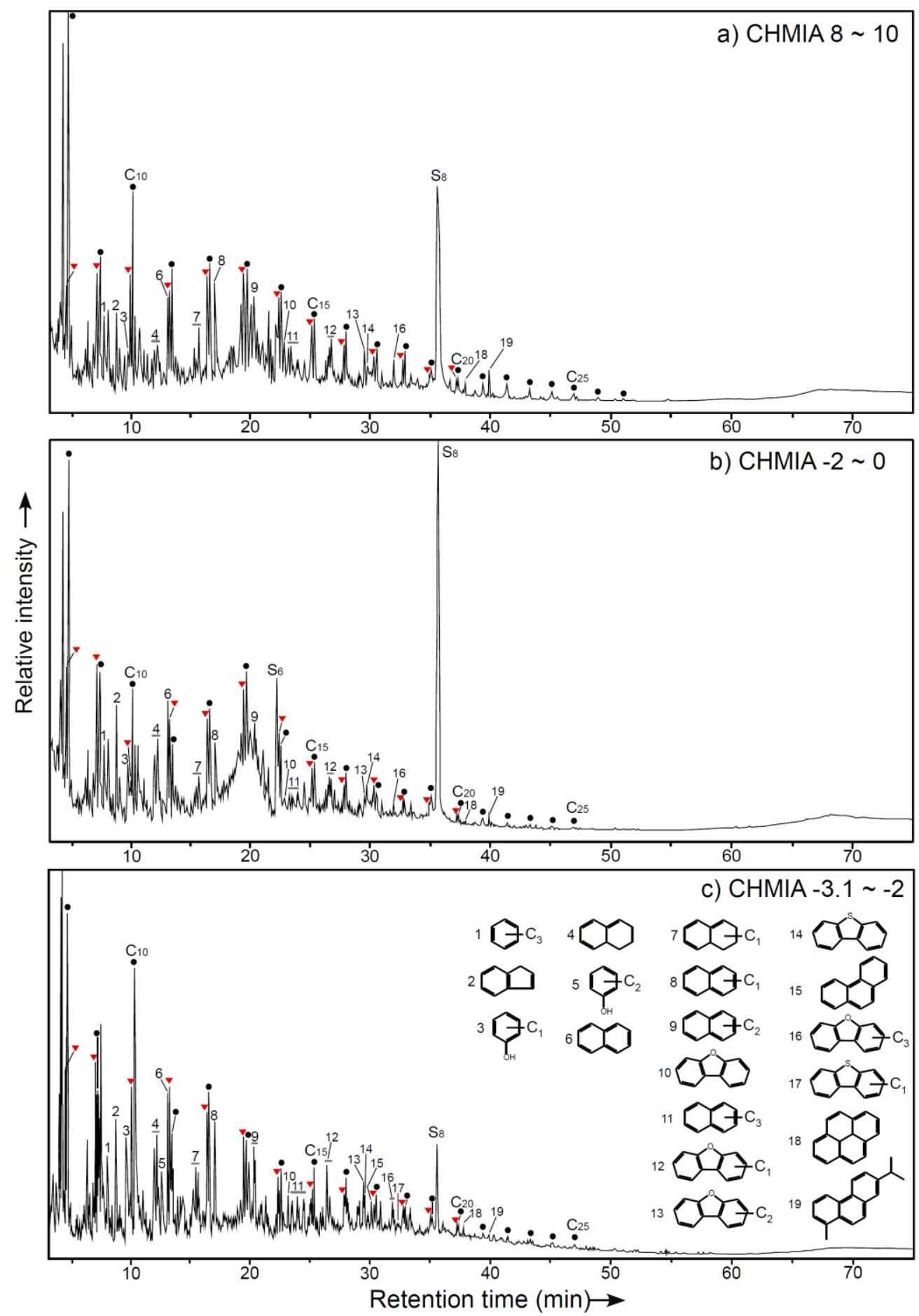

Fig. 5 Total ion chromatograms (TICs) of the pyrolysates of kerogens in the Meishan section A. Solid circles and triangles in TICs are $n$-alkanes and $n$-alkenes, respectively; $\mathrm{Cn}$ ( $\mathrm{n}$ is numeral) are their carbon numbers. $\mathrm{S}_{6}$ and $\mathrm{S}_{8}$ are molecular sulfurs. 1: $\mathrm{C}_{3}$-alkylbenzene; 2 : indene; 3 : $\mathrm{C}_{1}$-alkylphenol; 4: dehydronaphthalenes; 5: $\mathrm{C}_{2}$-alkylphenol; 6 : naphthalene; 7: methyl-dehydronaphthalenes; 8: methylnaphthalene; 9: dimethylnaphthalenes; 10: dibenzofuran; 11: trimethylnaphthalenes; 12: methyldibenzofurans; 13: dimethyldibenzofurans; 14: dibenzothiophene; 15: phenanthlene; 16: trimethyldibenzofurans; 17: methyldibenzothiophenes; 18: pyrene; 19: retene. 
a)
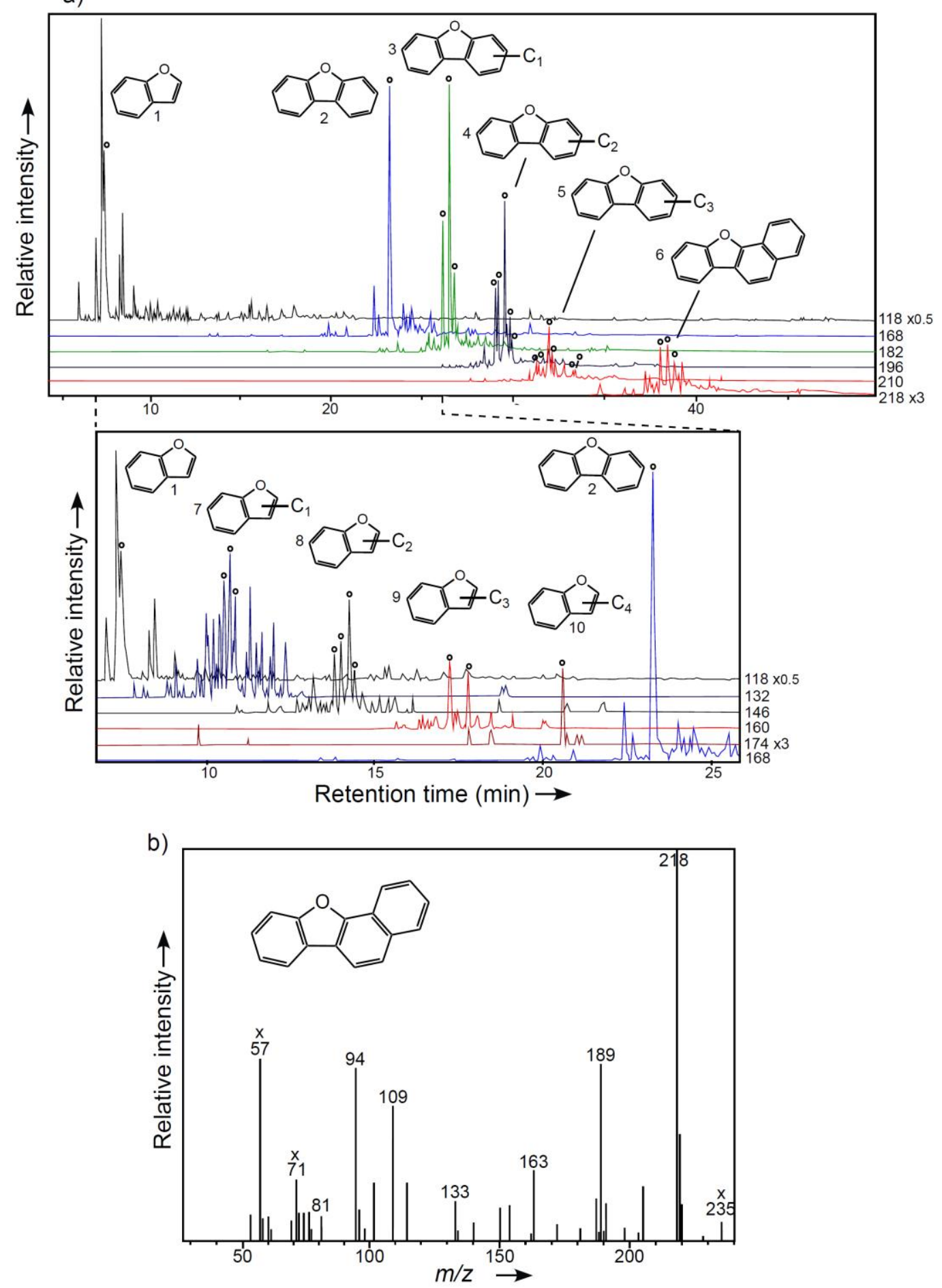

Fig. 6 (a) Mass fragmentograms of $m / z$ 118, 132, 146, 160, 168, 174, 182, 196, 210, and 218 of the pyrolysates from the kerogens from sample CHMIA-3.1 -2 cm. Open circles are aromatic furans; 1: benzofuran; 2: dibenzofuran; 3-5: mono-, di-, and tri-methyldibenzofurans, respectively; 6: benzonaphthofurans; 7-10: mono-, di-, tri-, and tetra-methylbenzofurans, respectively.

(b) Mass spectrum of a peak 6 in mass fragmentogram of $m / z$ 218, which can be identified as benzonaphthofuran. x: fragments that are possibly derived from other compound(s). 
a)

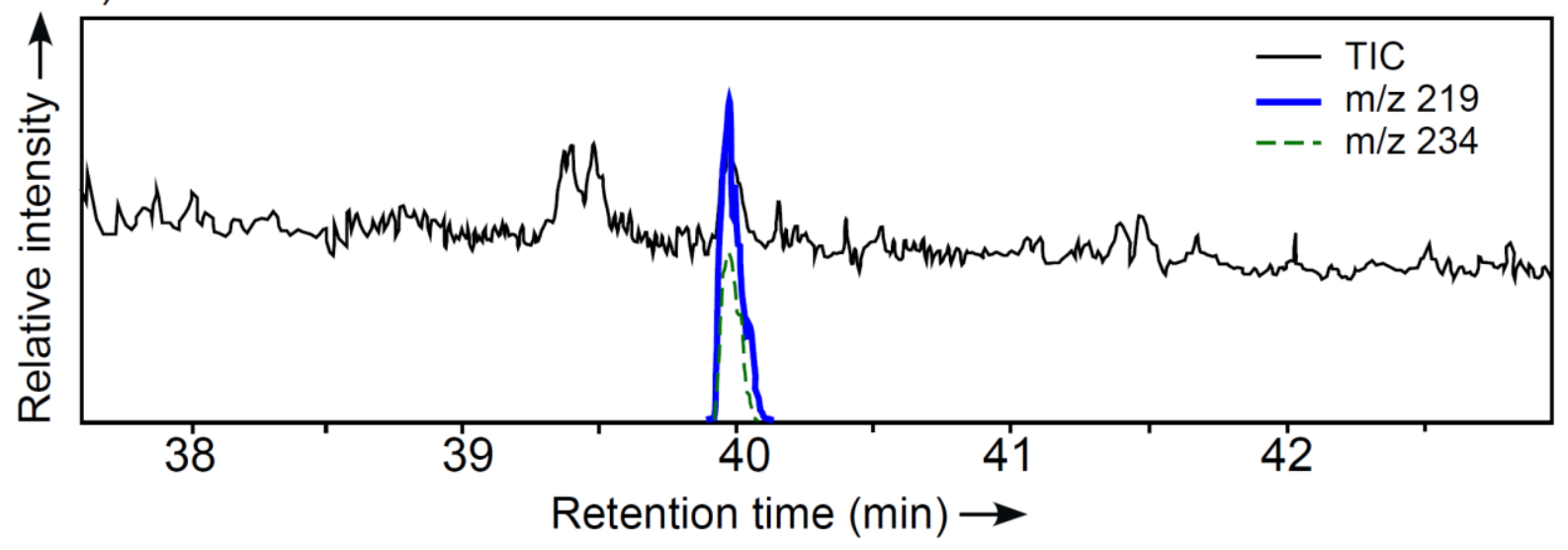

b)

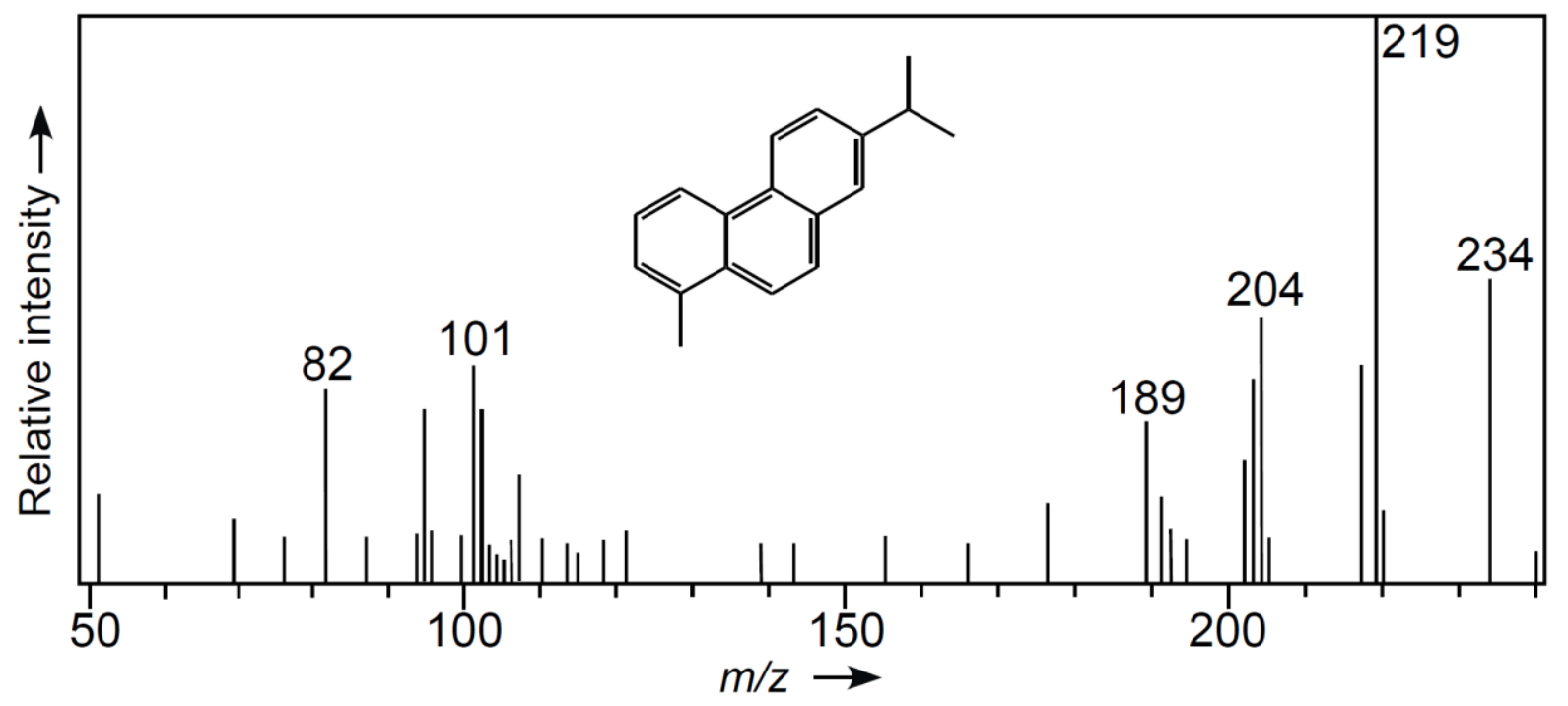

Fig. 7 (a) TIC and mass fragmentograms of $m / z 219$ and 234 of kerogen pyrolysates in a sample CHMIA-2 $0 \mathrm{~cm}$. (b) Mass spectrum of a peak in mass fragmentogram of $\mathrm{m} / z 219$ and 234, which can be identified as retene. 